\title{
THE HISTOLOGICAL CHANGES IN HYDANTOINATE GINGIVITIS
}

\author{
BY
}

\author{
L. CROME \\ From the Department of Neuropathology, the Fountain Hospital, London
}

(RECEIVED FOR PUBLICATION FEBRUARY 23, 1952)

The histological features of the gingival hypertrophy caused by the prolonged administration of hydantoinate drugs have been described by Glickman and Lewitus (1941), Ziskin, Stowe, and Zegarelli (1941), Zegarelli and Ziskin (1943), and by Esterberg and White (1945). The interval between the beginning dosage of the drug and the appearance of the gingival hypertrophy has varied within wide limits. Some cases were seen by Esterberg and White four years after its beginning, but neither they nor the previous workers have specified the duration of the gingival condition at the time of the biopsy. Some of the histological findings have given rise to concern over the possibility of malignant change intervening in the hyperplastic epithelium; Esterberg and White reported the opinion of certain pathologists that "malignancy could not be dismissed entirely." It is, therefore, of interest to record the following case in which histological examination has followed what might well be a longer period of continued epanutin administration than in those cases previously reported.

\section{Case Report}

The patient was admitted to the Fountain Hospital at the age of 3 years and 8 months with microcephaly, epilepsy, right-sided hemiplegia, and idiocy. She was given epanutin, gr. $\frac{3}{4}$ daily, for two years before her death, and hypertrophic gingivitis was noticed a year

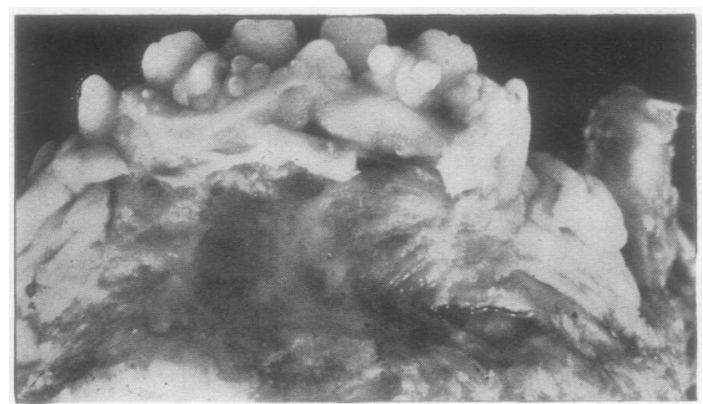

Fio. 1.-Papillary hypertrophy of mandibular gingival mucosa.

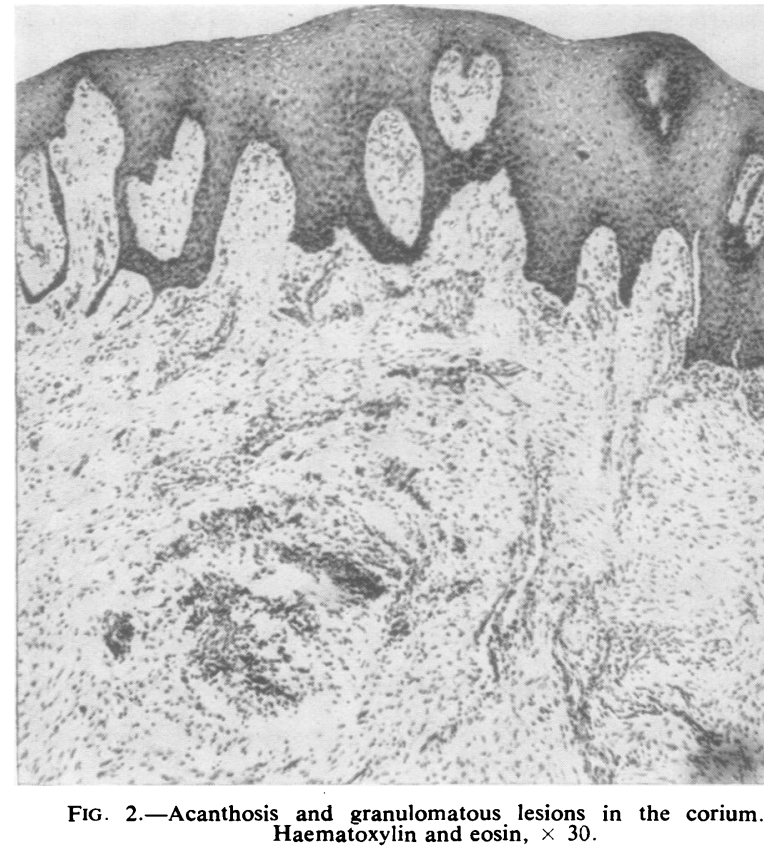

after treatment was begun, although it may have been present before. The patient died at the age of 12 in status epilepticus.

\section{Pathology}

The examination of the gums revealed extensive gingival hypertrophy (Fig. 1). The principal microscopical changes consisted of acanthosis and chronic inflammatory infiltration of the corium (Fig. 2). In addition to the acanthosis, the Malpighian layer showed elongation of the rete pegs and proliferation of the basal layer. Mitotic figures were absent. A few epithelial pearls were present in the elongated rete pegs. The dermal papillae were long, narrow, oedematous, and contained some polymorphonuclear leucocytes, lymphocytes, and plasma cells. The corium was thickened and consisted of interlacing bundles of young collagen 


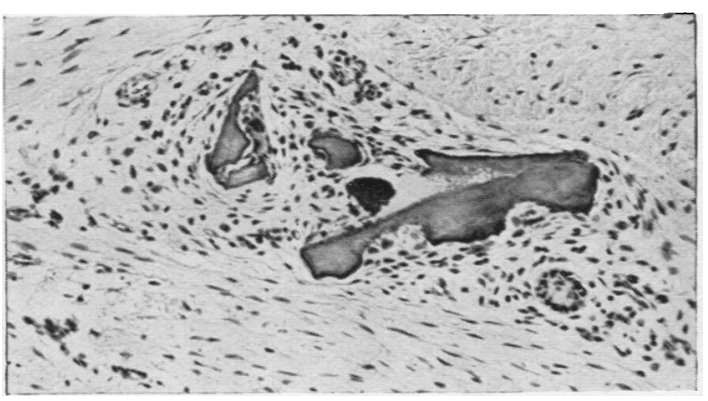

Fig. 3.-Partially calcified fragment. Haematoxylin and eosin, $\times 60$.

and an excessive number of capillaries. In many areas there was perivascular accumulation of plasma cells and lymphocytes. Some of these plasma cells were multinucleated. A few partially calcified fragments could be seen in the deeper layers of the corium. These were formed by osteoid tissue with a central calcified core and possessed no Haversian canals (Fig. 3).

\section{Discussion}

All the structural features described above have been observed and reported previously, although not all of them in any single case. The inflammatory infiltration and the number of plasma cells appear to have been more conspicuous in the present case. The proliferation of the epithelial cells, and the formation of pearls and papillae were equally striking in this instance, but there was no evidence of any malignant change.

\section{REFERENCES}

Esterberg, H. L., and White, P. H. (1945). J. Amer. dent. Ass., 32, 16. Glickman, I., and Lewitus, M. P. (1941). Ibid., 28, 199.

Zegarelli, E. V., and Ziskin, D. E. (1943). Amer. J. Orthodont. (Sect. Oral Surg.), 29, 152.

Ziskin, D. E., Stowe, L. R., and Zegarelli, E. V. (1941). Ibid., 27, 350 